\title{
Pengujian Alat Pemanen Energi Akustik Berbasis Loudspeaker Dengan Sumber Kebisingan Acak Dari Mesin Kendaraan Bermotor
}

\author{
Untung Adi Santosa ${ }^{1}$, Ikhsan Setiawan, dan Agung B.S. Utomo \\ Departemen Fisika, Fakultas Matematika dan Ilmu Pengetahuan Alam, Universitas Gadjah Mada \\ Sekip Utara BLS 21 Yogyakarta 33281 Indonesia \\ Email : untung.adi.s@mail.ugm.ac.id
}

\begin{abstract}
This paper reports the test results of a loudspeaker-based acoustic energy harvester with acoustic random noise sources from a motorcycle. The harvester consists of a quarter wavelength resonator and a subwoofer type loudspeaker with a nominal diameter of 6 inches. The motorcycle used in this experiment is $135 \mathrm{cc}$ Bajaj Pulsar motorsport with modified exhaust from the GBSMotosport Jakarta. The motor engine is operated at $3000 \mathrm{rpm}$, resulting in noise with a fluctuating Sound Pressure Level (SPL) in the range of (90-93) dB. Six variations of resonator lengths are used, those are $21 \mathrm{~cm}, 31 \mathrm{~cm}, 58 \mathrm{~cm}, 85 \mathrm{~cm}, 112 \mathrm{~cm}$, and $139 \mathrm{~cm}$. In this test, data of dominant frequency, $S P L$, and output rms voltage were taken for 15 minutes. The rms voltage is measured at $100 \Omega$ load resistor. The results show that the $112 \mathrm{~cm}$ resonator produces the highest average rms electrical power, that is $(0.21 \pm 0.01) \mathrm{mW}$, which is obtained at frequency that fluctuates within (95-120) Hz. In addition, with random sound sources, SPL and its dominant frequency fluctuate greatly, so it will greatly affect the generated electric power. Further research is needed to enhance the output electrical power and anticipate the impact of frequency fluctuation which exists in random noise sources.
\end{abstract}

Keywords: Acoustic energy harvester, loudspeaker, acoustic resonator, random noise, electric power

\begin{abstract}
Abstrak: Paper ini memaparkan hasil pengujian alat pemanen energi akustik berbasis loudspeaker dengan sumber kebisingan acak dari mesin kendaraan bermotor. Alat pemanen energi akustik ini terdiri dari resonator seperempat panjang gelombang dan loudspeaker jenis subwoofer dengan diameter nominal 6 inci. Sumber kebisingan yang digunakan adalah motor Bajaj Pulsar 135 cc dengan knalpot modifikasi dari GBS-Motosport Jakarta. Mesin motor dioperasikan pada laju putaran tetap $3000 \mathrm{rpm}$, sehingga menghasilkan kebisingan dengan SPL (sound pressure level) yang berfluktuasi dalam interval (90-93) dB. Digunakan enam variasi panjang resonator, yaitu $21 \mathrm{~cm}, 31 \mathrm{~cm}, 58 \mathrm{~cm}, 85$ $\mathrm{cm}, 112 \mathrm{~cm}$, dan $139 \mathrm{~cm}$. Dalam pengujian ini, data frekuensi dominan kebisingan, $S P L$ kebisingan, dan tegangan keluaran alat pemanen energi akustik diambil selama 15 menit. Tegangan $r m s$ keluaran diukur pada resistor beban $100 \Omega$. Hasil eksperimen menunjukkan bahwa resonator dengan panjang $112 \mathrm{~cm}$ menghasilkan daya listrik rms rata-rata tertinggi yaitu sebesar $(0,21 \pm 0,01) \mathrm{mW}$, diperoleh pada frekuensi yang berfluktuasi antara $95 \mathrm{~Hz}$ sampai $120 \mathrm{~Hz}$. Selain itu, hasil eksperimen ini menunjukkan bahwa dengan sumber bunyi acak, SPL kebisingan dan frekuensi dominannya sangat berfluktuasi, sehingga akan sangat berpengaruh terhadap daya listrik yang dihasilkan. Penelitian lebih lanjut diperlukan untuk meningkatkan daya listrik keluaran dan mengantisipasi dampak fluktuasi frekuensi sumber kebisingan acak.
\end{abstract}

Kata kunci: Pemanen energi akustik, loudspeaker, resonator akustik, kebisingan acak, energi listrik

\section{PENDAHULUAN}

Kurangnya ketersediaan energi listrik dapat menyebabkan produktivitas masyarakat menjadi terganggu dan menurun. Masalah ketersediaan energi listrik di Indonesia timbul akibat kebutuhan energi listrik yang meningkat lebih pesat dibandingkan dengan kemampuan PT PLN untuk memenuhi pasokan listrik yang dibutuhkan. Sepanjang tahun 2016, konsumsi 
energi listrik di Indonesia sebesar 216.004,32 GWh (sektor industri 68.145,32 GWh, sektor rumah tangga sebesar 93.634,63 GWh, sektor komersial sebesar 14.149,99 GWh dan sektor publik atau umum sebesar 14.149,99 GWh). Dibandingkan dengan tahun 2015, konsumsi tersebut naik sebesar 13.158,50 GWh atau 6,48\%, sedangkan kapasitas produksi PLN hanya mampu menghasilkan energi listrik sebesar 183.808,97 GWh (Triboesono, 2017).

Sebagai solusi untuk mengatasi masalah tersebut, saat ini muncul berbagai penelitian dan inovasi terkait energi baru terbarukan dari berbagai sumber. Bahkan, saat ini muncul inovasi baru yang memanfaatkan energi kebisingan di lingkungan untuk dimanfaatkan menjadi energi listrik atau yang sering disebut dengan pemanenan energi akustik. Pemanenan energi akustik merupakan proses penangkapan energi akustik (bunyi) yang ada di lingkungan dan mengubahnya menjadi energi listrik yang dapat lebih bermanfaat bagi manusia (Pillai dan Deenadayalan, 2014).

Untuk meningkatkan daya dan efisiensi alat pemanen energi akustik saat ini banyak dilakukan penelitian terkait pengaruh resonator akustik dan transduser akustik. Setiawan (2019) telah melakukan pengujian tentang pemanen energi akustik menggunakan transduser loudspeaker baik dengan resonator seperempat panjang gelombang $(133 \mathrm{~cm})$ maupun tanpa resonator. Hasil eksperimen menunjukkan bahwa pada frekuensi bunyi $62 \mathrm{~Hz}$ dan SPL 105 $\mathrm{dB}$ loudspeaker tanpa resonator mampu menghasilkan daya listrik rms sebesar $0,78 \mathrm{~mW}$, sedangkan dengan menggunakan resonator sepanjang $133 \mathrm{~cm}$ dapat menghasilkan daya listrik rms sebesar 20,7 mW dari bunyi dengan frekuensi $92 \mathrm{~Hz}$ dan SPL $105 \mathrm{~dB}$ (Setiawan, 2019). Sifa (2018) telah melakukan pengujian untuk mengetahui pengaruh panjang resonator seperempat panjang gelombang terhadap daya yang dihasilkan oleh pemanen energi akustik dengan variasi panjang resonator, yaitu $21 \mathrm{~cm}, 31 \mathrm{~cm}, 58 \mathrm{~cm}, 85 \mathrm{~cm}, 112 \mathrm{~cm}$, dan $139 \mathrm{~cm}$. Hasil dari eksperimen ini menunjukkan bahwa ada dua panjang resonator yang optimal yaitu $85 \mathrm{~cm}$ dengan frekuensi optimum $42 \mathrm{~Hz}$ dan $112 \mathrm{~cm}$ dengan frekuensi optimum $72 \mathrm{~Hz}$. Resonator dengan panjang $85 \mathrm{~cm}$ pada frekuensi optimum mampu menghasilkan daya listrik sebesar $(0,44 \pm 0,06) \mathrm{mW}$, dan resonator dengan panjang $112 \mathrm{~cm}$ pada frekuensi optimum mampu menghasilkan daya sebesar $(0,28 \pm 0,01) \mathrm{mW}$ (Sifa, 2018). Selain itu, Dimastya (2018) telah melakukan pengujian alat pemanen energi akustik menggunakan resonator Helmholtz dengan variasi panjang leher resonator Helmhotz. Hasil dari eksperimen ini menunjukkan bahwa daya output dari alat pemanen energi akustik yang optimum diperoleh dengan panjang leher resonator $2 \mathrm{~cm}$, yaitu sebesar 2,35 $\mathrm{mW}$ dan 1,28 $\mathrm{mW}$ masing-masing pada frekuensi $41 \mathrm{~Hz}$ dan $83 \mathrm{~Hz}$ dengan SPL $100 \mathrm{~dB}$ (Dimastya, 2018).

Horowitz dkk. (2006) mengembangkan sebuah alat pemanen energi akustik dengan menggunakan piezoelektrik. Alat yang diciptakan terdiri atas sebuah Lead Zirconate Titanate (PZT) diafragma yang terikat pada bagian bawah resonator Helmhotz. Pemanen energi akustik dengan total volume $2.445 \mathrm{~cm}^{3}$ memiliki total impedansi $980 \Omega$. Pada keadaan yang optimal, diperoleh puncak daya $6 \mathrm{pW}$ pada frekuensi 13,57 kHz dan $149 \mathrm{~dB}$ (Horowitz dkk., 2006). Khan dan Izhar (2016) membuat sebuah pemanen energi akustik elektromagnetik untuk sensor nirkabel otonom. Pemanen energi akustik yang dibuat terdiri dari resonator Helmhotz, diafragma lateks, dua magnet $\mathrm{NdFeB}$, dan sebuah koil dengan total volume 7,86 $\mathrm{cm}^{3}$. Kondisi beban optimal pemanen ini adalah $66 \Omega$. Dalam frekuensi $144 \mathrm{~Hz}$ dan SPL 120 $\mathrm{dB}$ berhasil dihasilkan puncak daya sebesar 1,5 mW (Khan dan Izhar, 2016). Selanjutnya, Fatikasari (2018) melakukan pengujian secara eksperimen tentang pengaruh variasi jenis loudspeaker terhadap energi listrik yang dihasilkan. Hasil dari eksperimen ini menunjukkan bahwa semakin naiknya SPL menghasilkan daya listrik keluaran yang cenderung bertambah secara eksponensial, dan nilai maksimum daya listrik output diperoleh dengan menggunakan loudspeaker jenis full range dengan diameter nominal 10 inci (Fatikasari, 2018). 
Penelitian pemanen energi akustik tersebut di atas dilakukan di laboratorium dengan frekuensi dan $S P L$ kebisingan yang dapat dikontrol. Di sisi lain, untuk dapat mengaplikasikan alat pemanen energi akustik dibutuhkan adanya uji lapangan karena kondisi di lapangan dapat jauh berbeda dengan kondisi dalam laboratorium, yaitu bahwa frekuensi dan $S P L$ kebisingan di lapangan secara umum bersifat acak dan tak terkendali. Oleh karena itu dalam makalah ini dibahas tentang pengujian alat pemanen energi akustik dengan sumber kebisingan sesungguhnya, dalam hal ini dipilih sumber kebisingan berupa mesin kendaraan bermotor. Adapun alat yang diuji adalah alat pemanen energi akustik yang berbasis loudspeaker, yaitu menggunakan loudspeaker sebagai transduser akustik yang mengkonversi energi bunyi menjadi energi listrik, dan dilengkapi dengan resonator akustik seperempat panjang gelombang yang bentuk pipa lurus. Penelitian ini bertujuan untuk mengetahui efektivitas alat pemanen energi akustik dalam mengkonversi energi akustik menjadi energi listrik dalam keadaan sesungguhnya di lapangan dari sumber kebisingan yang bersifat acak.

\section{METODE PENELITIAN}

Penelitian ini dilakukan melalui tahap-tahap sebagaimana dipaparkan berikut ini.

\subsection{Pemilihan sumber kebisingan acak yang tepat}

Sumber kebisingan yang digunakan dalam penelitian ini merupakan sumber kebisingan acak yang biasa ditemui di lingkungan. Sebagai tahap awal diperlukan adanya penentuan sumber kebisingan acak yang tepat untuk dapat digunakan dalam penelitian. Sumber kebisingan acak yang dipilih harus memiliki tingkat kebisingan $(S P L)$ lebih dari $80 \mathrm{~dB}$. Hal ini dikarenakan dengan tingkat kebisingan di atas $80 \mathrm{~dB}$, daya yang dihasilkan oleh alat pemanen energi akustik akan bertambah eksponensial seiring dengan bertambahnya $S P L$, sehingga daya yang diperoleh lebih maksimal (Sifa, 2018). Sumber kebisingan acak yang dipilih mesin kendaraan bermotor, dalam hal ini dipilih sepeda motor Pulsar 135 cc dengan knalpot midifikasi dari GBS Motosport Jakarta. Sumber kebisingan acak tersebut telah diuji menggunakan $S P L$-meter terlebih dahulu dan menunjukkan nilai $S P L$ lebih dari $80 \mathrm{~dB}$ sehingga dinilai cocok untuk dijadikan sumber kebisingan acak dalam penelitian ini.

\subsection{Persiapan resonator akustik dengan variasi panjang}

Resonator akustik yang digunakan adalah resonator lurus seperempat panjang gelombang $(\lambda / 4)$ yang terbuat dari pipa PVC Rucika dengan diameter nominal $6 \mathrm{~cm}$. Beberapa potongan pipa dipersiapkan untuk kemudian dikombinasikan sehingga diperoleh panjang resonator yang bervariasi. Dalam hal ini, variasi panjang resonator $\left(L_{R}\right)$ yang digunakan adalah $21 \mathrm{~cm}$, $31 \mathrm{~cm}, 58 \mathrm{~cm}, 85 \mathrm{~cm}, 112 \mathrm{~cm}$, dan $144 \mathrm{~cm}$. Pemilihan variasi panjang resonator ini merupakan tindak lanjut dari penelitian skala laboratorium yang telah dilakukan oleh Sifa (2018). Pada salah satu ujung resonator akan dipasang loudspeaker konversi, sedangkan ujung lainnya terbuka ke lingkungan sehingga suara kebisingan dapat masuk ke dalam resonator dan diterima oleh loudspeaker konversi.

\subsection{Penyusunan peralatan eksperimen}

Peralatan eksperimen disusun seperti ditunjukkan oleh skema dalam Gambar 1(a), sedangkan foto peralatan eksperimen untuk pengujian diperlihatkan oleh Gambar 1(b). Alat pemanen energi akustik yang digunakan dalam eksperimen terdiri dari resonator $\lambda / 4$ lurus dan loudspeaker jenis subwoofer diameter nominal 6 inci. Ujung resonator yang terbuka ditempatkan menghadap knalpot kendaraan bermotor dengan jarak sekitar $20 \mathrm{~cm}$. Selain itu, $S P L$-meter dan handphone dengan aplikasi audio frekuensi-meter yang telah dikalibrasi 
ditempatkan tepat di ujung terbuka resonator masing-masing untuk mengukur SPL dan frekuensi kebisingan yang ditimbulkan oleh mesin kendaraan bermotor.
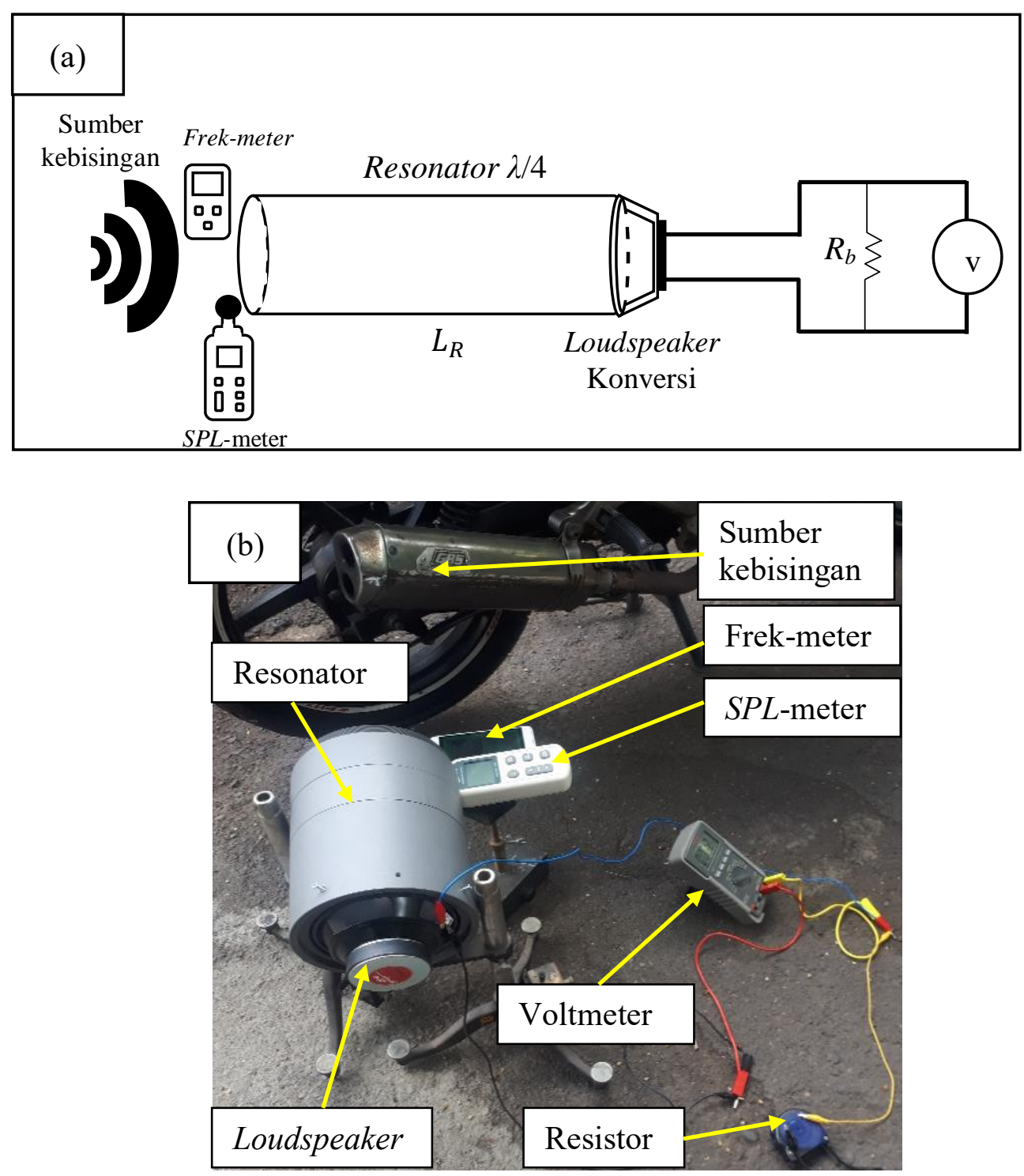

Gambar 1. (a) Skema percobaan, (b) Susunan pereralatan saat pengambilan data dengan panjang resonator $21 \mathrm{~cm}$

Loudspeaker konversi ditempatkan di bagian belakang atau bagian yang berlawanan dengan ujung terbuka resonator dan dihubungkan secara paralel dengan hambatan beban $\left(R_{b}\right)$. Loudspeaker tersebut akan mengubah gelombang-gelombang bunyi di dalam resonator menjadi arus listrik bolak-balik yang melalui hambatan beban. Selanjutnya, sebuah voltmeter digital dipasang paralel dengan hambatan beban $100 \Omega$ yang digunakan untuk mengukur tegangan $r m s\left(V_{r m s}\right)$ antara kedua ujung hambatan beban tersebut.

\subsection{Eksperimen dan analisa data}

Tahap pengujian alat pemanen energi akustik dilakukan dengan mengukur $S P L$ kebisingan, frekuensi kebisingan, dan $V_{r m s}$ pada resistor beban yang dihasilkan dari suara kebisingan 
mesin kendaraan bermotor setiap 30 detik sekali dalam waktu 15 menit hingga diperoleh 30 data percobaan untuk setiap variasi panjang resonator. Dalam pengambilan data tersebut, mesin kendaraan bermotor dioperasikan dalam keadaan stasioner pada putaran mesin 3000 rpm (revolusi per menit). Laju putaran mesin tersebut dipilih karena pada keadaan tersebut telah teramati bahwa SPL kebisingan cukup tinggi, yaitu berfluktuasi dari $90 \mathrm{~dB}$ sampai 94 dB. Pengukuran $S P L$ kebisingan ini dilakukan dengan menggunakan $S P L$-meter, sedangkan frekuensi kebisingan $(f)$ diukur dengan menggunakan handphone dengan aplikasi audio frekuensi-meter yang terkalibrasi, dan tegangan $V_{r m s}$ diukur dengan voltmeter digital. Data $V_{r m s}$ ini kemudian dikonversi menjadi daya listrik rms $\left(P_{r m s}\right)$ dengan menggunakan persamaan

$$
P_{r m s}=\frac{V_{r m s}^{2}}{R_{b}}
$$

Data yang terkumpul selanjutnya dianalisis melalui grafik-grafik $P_{r m s}$ versus , $S P L$ versus $t, f$ versus $t, P_{r m s}$ versus $L_{R}, P_{r m s}$ versus $S P L$, dan $P_{r m s}$ versus $f$. Terakhir, dari analisis data yang telah dilakukan, untuk mengetahui efektivitas pemanen energi akustik di lapangan dilakukan perbandingan hasil eksperimen di lapangan dengan hasil eksperimen di laboratorium yang telah dilakukan oleh Sifa (2018).

\section{HASIL DAN PEMBAHASAN}

\subsection{Variasi Panjang Resonator}

Hasil perhitungan daya listrik $r m s$ yang dihasilkan $\left(P_{r m s}\right)$ untuk setiap variasi panjang resonator pada kondisi putaran mesin 3000 rpm ditunjukkan oleh Gambar 2. Pada gambar tersebut terlihat bahwa $P_{r m s}$ setiap waktu berfluktuasi dalam interval tertentu. Fluktuasi tersebut terjadi karena nilai $S P L$ dan frekuensi bunyi kebisingan yang selalu berfluktuasi dalam keadaan kebisingan acak. Dari gambar tersebut juga tampak bahwa $P_{r m s}$ dari resonator dengan panjang $112 \mathrm{~cm}$ dan $139 \mathrm{~cm}$ merupakan $P_{r m s}$ yang paling sensitif terhadap adanya perubahan frekuensi kebisingan. Hal tersebut diduga terjadi karena frekuensi resonansi pada tangga nada ke-1 dari resonator $112 \mathrm{~cm}$ yaitu sekitar $78 \mathrm{~Hz}$ dan frekuensi resonansi tangga nada ke-1 dari resonator $112 \mathrm{~cm}$ yaitu $63 \mathrm{~Hz}$ mendekati nilai frekuensi resonansi dari loudspeaker konversi yang digunakan yaitu $76 \mathrm{~Hz}$ (Fatikasari, 2018). Oleh karena itu tegangan $r m s$ dan juga daya $r m s$ yang dihasilkan akan semakin berfluktuasi dan tidak stabil. 


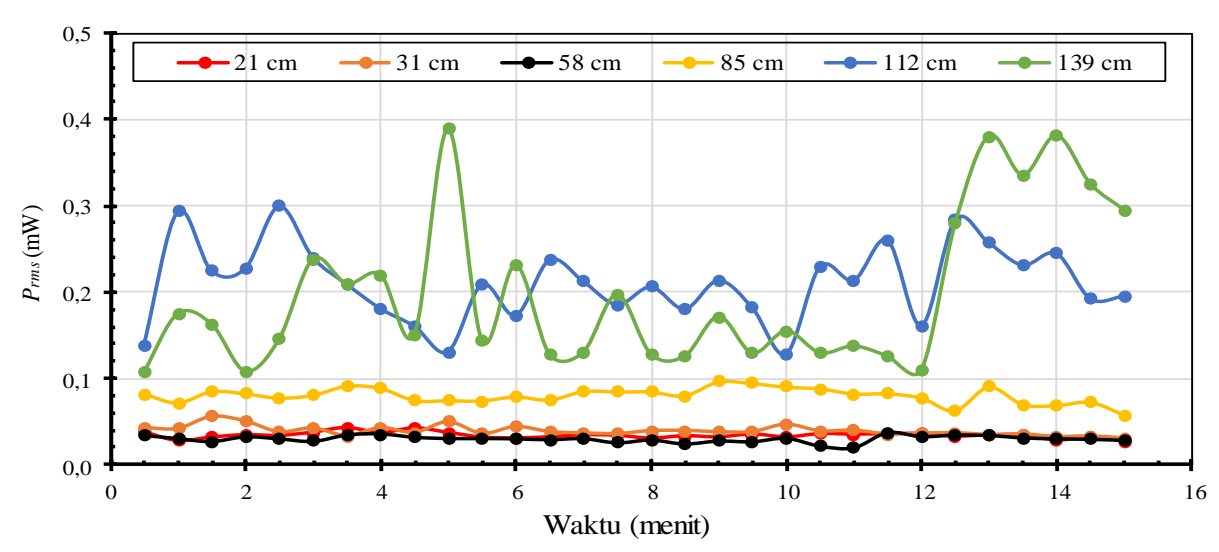

Gambar 2. Daya listrik rms $\left(P_{r m s}\right)$ yang dihasilkan oleh loudspeaker konversi dengan berbagai panjang resonator. Data diambil tiap selang waktu 30 detik selama 15 menit. Garis penghubung antar titik-titik data digunakan untuk memandu pandangan mata.

Selanjutnya, untuk mengetahui panjang resonator yang paling optimal dalam menghasilkan $P_{r m s}$ rerata tertinggi diperlukan adanya perbandingan nilai $P_{r m s}$ rerata untuk setiap variasi panjang resonator. Dalam hal ini, nilai $P_{r m s}$ rerata dari alat pemanen energi akustik dengan berbagai panjang resonator diperlihatkan oleh Gambar 3. Dari gambar tersebut terlihat bahwa resonator dengan panjang $112 \mathrm{~cm}$ paling optimal dalam menghasilkan daya listrik, yaitu menghasilkan $P_{r m s}$ rerata tertinggi sebesar $(0,21 \pm 0,01) \mathrm{mW}$. Hal tersebut terjadi dikarenakan resonator dengan panjang $112 \mathrm{~cm}$ merupakan resonator dengan frekuensi resonansi yang paling mendekati frekuensi resonansi loudspeaker yang digunakan. Hasil ini juga sesuai dengan hasil penelitian di laboratorium yang telah dilakukan oleh Sifa (2018) bahwa resonator dengan panjang $112 \mathrm{~cm}$ mampu menghasilkan daya listrik yang maksimum yaitu $(0,28 \pm 0,01) \mathrm{mW}$ pada SPL $100 \mathrm{~dB}$ (Sifa, 2018). Oleh karena hasil tersebut, dapat dikatakan bahwa alat pemanen energi akustik berbasis loudspeaker ini efektif untuk diaplikasikan di lapangan. selanjutnya dibahas lebih rinci mengenai hasil pengujian alat dengan panjang resonator $112 \mathrm{~cm}$.

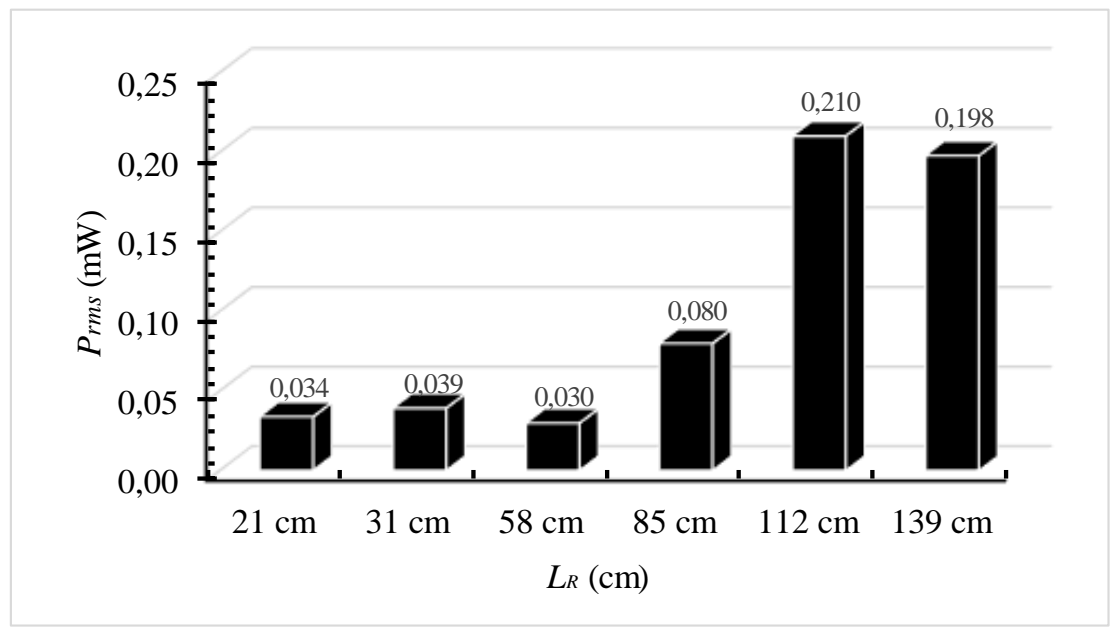

Gambar 3. Daya listrik rms $\left(P_{r m s}\right)$ rata-rata dari setiap variasi panjang resonator. 


\subsection{Panjang resonator $112 \mathrm{~cm}$}

Setiap variasi panjang resonator alat pemanen energi akustik dilakukan pengujian dengan kondisi yang sama yaitu menggunakan sumber kebisingan acak dari mesin kendaraan bermotor. Keadaan dimana kebisingan tidak teratur (di lapangan) akan berpengaruh terhadap nilai tingkat kebisingan $S P L$, frekuensi kebisingan, dan nilai tegangan $r m s\left(V_{r m s}\right)$ yang berfluktuasi dan tidak dapat dikontrol setiap waktunya.

\subsubsection{Sebaran daya listrik rms terhadap SPL kebisingan dan frekuensi kebisingan}

Daya listrik rms hasil perhitungan tersebar secara acak untuk setiap tingkat kebisingan $S P L$ dan frekuensi kebisingan. Sebaran nilai daya listrik $r m s$ terhadap nilai $S P L$ kebisingan dari sumber kebisingan acak terlihat pada Gambar 4. Tampak bahwa mayoritas nilai daya listrik rms berada pada rentang $S P L$ kebisingan dari $91 \mathrm{~dB}$ hingga $93 \mathrm{~dB}$. Dalam rentang nilai $S P L$ tersebut muncul berbagai nilai $P_{r m s}$ keluaran. Perbedaan nilai $P_{r m s}$ dalam rentang $S P L$ tersebut dapat disebabkan karena nilai frekuensi dominan kebisingan untuk setiap $S P L$ selalu berfluktuasi. Saat frekuensi dominan kebisingan dekat frekuensi resonansi resonator, $P_{r m s}$ cenderung besar. Sebaliknya, saat frekuensi dominan kebisingan jauh dari frekuensi resonansi resoantor, $P_{r m s}$ cenderung kecil. Meskipun nilai $S P L$ dalam kedua kasus tersebut sama atau hampir sama. Selain itu, dari data sebaran tersebut diperoleh daya listrik $r m s$ tertinggi dari $S P L$ kebisingan $93 \mathrm{~dB}$, yaitu sebesar $(0,29 \pm 0,01) \mathrm{mW}$.

Selanjutnya sebaran $P_{r m s}$ terhadap frekuensi dominan kebisingan dari sumber kebisingan acak terlihat pada Gambar 5. Terlihat dengan jelas bahwa mayoritas $P_{r m s}$ terukur pada daerah frekuensi dari $95 \mathrm{~Hz}$ sampai $120 \mathrm{~Hz}$. Bahkan $P_{r m s}$ tertinggi diperoleh ketika frekuensi dominan kebisingan berada pada daerah frekuensi tersebut, khususnya dalam daerah frekuensi dari $98 \mathrm{~Hz}$ sampai $113 \mathrm{~Hz}$.

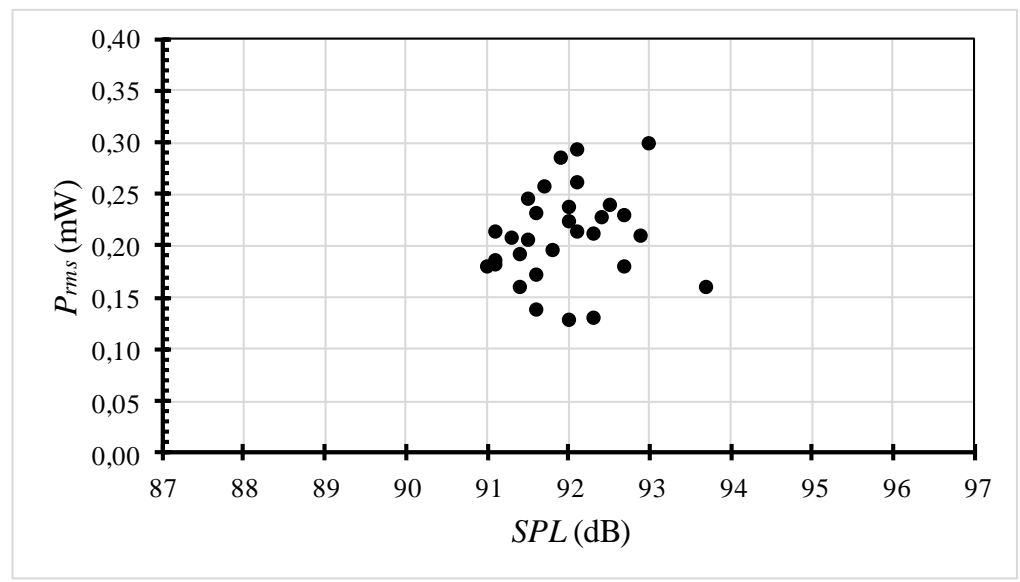

Gambar 4. Persebaran hasil perhitungan daya listrik rms setiap nilai tingkat kebisingan 


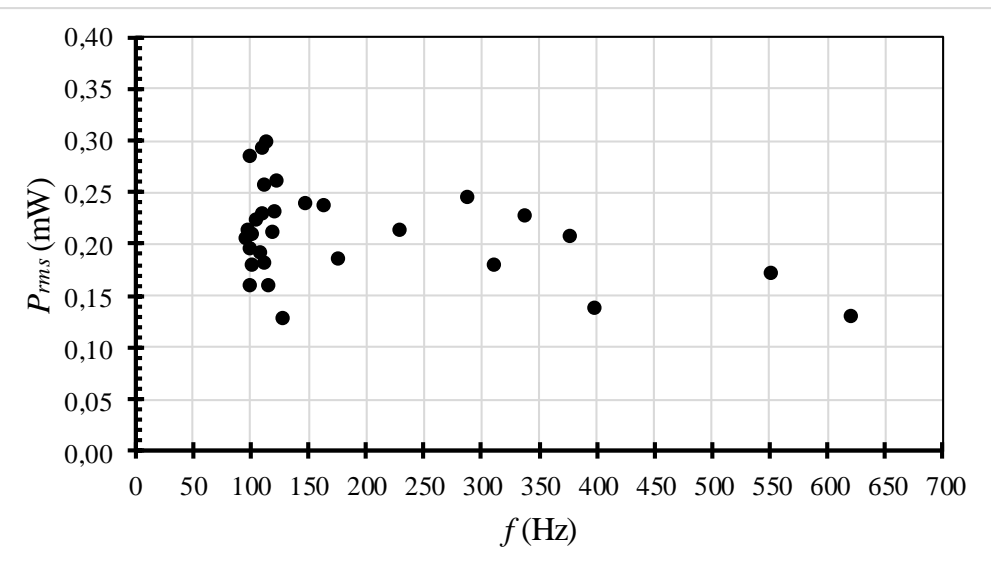

Gambar 5. Persebaran hasil perhitungan daya listrik $r m s$ setiap nilai frekuensi kebisingan

\subsubsection{Fluktuasi SPL kebisingan, frekuensi kebisingan, dan daya listrik rms tehadap waktu}

Gambar 6 memperlihatkan (a) fluktuasi nilai SPL kebisingan, (b) frekuensi kebisingan, dan (c) daya listrik rms $\left(P_{r m s}\right)$ yang dihasilkan untuk setiap saat pengambilan data. Pada Gambar 6(a) terlihat bahwa pada kondisi putaran mesin $3000 \mathrm{rpm}$ nilai SPL kebisingan berfluktuasi dari $91 \mathrm{~dB}$ sampai 93,7 dB dengan rerata $S P L$ kebisingan sekitar 92,9 dB. Lebar daerah fluktuasi sebesar 2,7 dB menunjukkan bahwa nilai $S P L$ kebisingan selama 15 menit pengambilan data berfluktuasi relatif kecil. Dalam keadaan terkontrol seharusnya dengan kondisi putaran mesin konstan pada $3000 \mathrm{rpm}$ nilai tingkat kebisingan akan konstan. Akan tetapi karena keadaan tidak bisa dikontrol, nilai tingkat kebisingan berfluktuasi untuk setiap waktunya. Hal ini dapat disebabkan karena dalam kondisi di lapangan banyak terdapat suara dari lingkungan yang dapat mempengaruhi kebisingan dari mesin kendaraan bermotor.

Selanjutnya Gambar 6(b) memperlihatkan bahwa nilai frekuensi dominan kebisingan dari sumber kebisingan acak mesin kendaraan bermotor sangat berfluktuasi. Fluktuasi tersebut berkisar dari $96 \mathrm{~Hz}$ sampai $621 \mathrm{~Hz}$. Loncatan nilai frekuensi kebisingan yang relatif besar terjadi sebanyak tujuh kali dari total 30 data percobaan yaitu pada menit ke-0,5 sebesar 398 Hz, menit ke-2 sebesar $338 \mathrm{~Hz}$, ke-5 sebesar $621 \mathrm{~Hz}$, menit ke-5,5 sebesar $376 \mathrm{~Hz}$, menit ke-6 sebesar $550 \mathrm{~Hz}$, menit ke-8,5 sebesar $311 \mathrm{~Hz}$, dan menit ke-14 sebesar $288 \mathrm{~Hz}$. Meskipun fluktuasi yang terjadi pada frekuensi kebisingan sangat besar, akan tetapi mayoritas frekuensi dominan kebisingan dari mesin kendaraan bermotor yang digunakan hanya berkisar dari 100 Hz sampai $120 \mathrm{~Hz}$ (pada $3000 \mathrm{rpm}$ ).

Terakhir, fluktuasi daya listrik rms $\left(P_{r m s}\right)$ yang dihasilkan oleh alat pemanen energi akustik ini ditunjukkan oleh Gambar 6(c). Fluktuasi tersebut terutama disebabkan karena adanya pengaruh dari nilai SPL kebisingan dan frekuensi kebisingan. Nilai SPL yang tinggi dapat menyebabkan $P_{r m s}$ yang dihasilkan tinggi, begitu pula sebaliknya $S P L$ yang rendah akan menghasilkan $P_{r m s}$ yang rendah. Di sisi lain, nilai frekuensi dominan kebisingan yang jauh dari nilai frekuensi-frekuensi resonansi resonator maupun loudspeaker akan menyebabkan $P_{r m s}$ yang dihasilkan rendah meskipun SPL kebisingan saat itu tinggi. Sebaliknya, nilai frekuensi dominan kebisingan yang dekat dengan nilai frekuensi-frekuensi resonansi resonator maupun loudspeaker akan menyebabkan $P_{r m s}$ yang dihasilkan cukup tinggi meskipun $S P L$ kebisingan saat itu relatif rendah. Sebagai salah satu contoh tingginya nilai $P_{r m s}$ pada menit ke-1 dan menit ke-2,5 disebabkan karena nilai frekuensi kebisingan pada saat itu sebesar $110 \mathrm{~Hz}$ dan $113 \mathrm{~Hz}$, yang mana kedua frekuensi kebisingan tersebut dekat dengan nilai frekuensi-frekuensi resonansi resonator maupun loudspeaker. Contoh lain, 
rendahnya nilai $P_{r m s}$ pada menit ke-0,5 dan menit ke-5 disebabkan karena nilai frekuensi kebisingan pada saat itu berturut-turut adalahr $398 \mathrm{~Hz}$ dan $621 \mathrm{~Hz}$ yang sangat jauh dari frekuensi resonansi resonator maupun loudspeaker, meskipun nilai $S P L$ saat itu relatif tinggi (91,6 dB dan 92,3 dB).
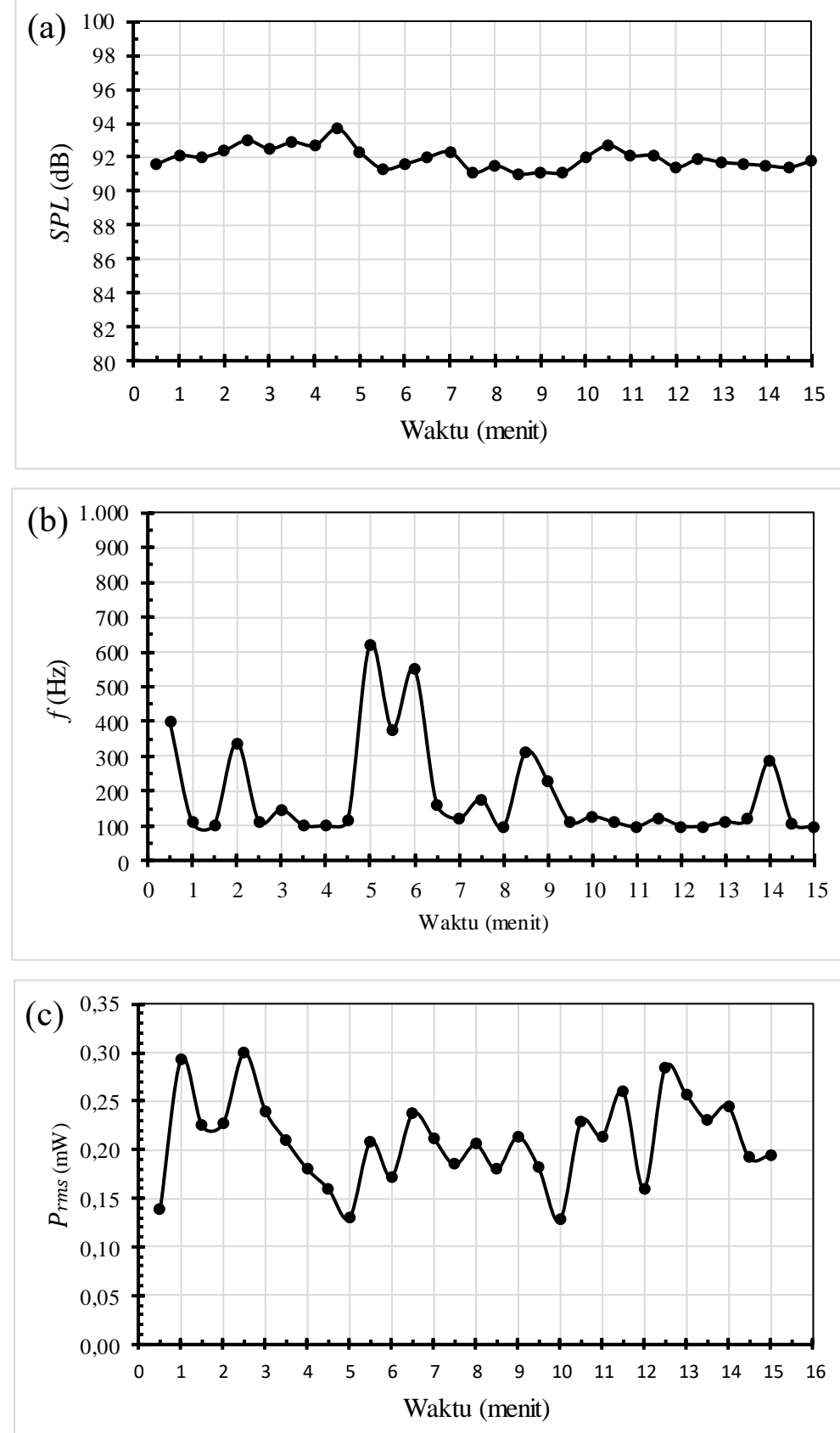

Gambar 6. Fluktuasi (a) tingkat $S P L$ kebisingan, (b) frekuensi kebisingan, dan (c) daya listrik $r m s\left(P_{r m s}\right)$ untuk setiap variasi waktu pengujian. Garis penghubung antar titik-titik data digunakan untuk memandu pandangan mata.

\section{KESIMPULAN}

Hasil-hasil eksperimen dalam penelitian ini menunjukkan bahwa sumber kebisingan acak di lapangan akan menghasilkan tingkat kebisingan SPL dan frekuensi kebisingan yang berfluktuasi. Dalam penelitian ini fluktuasi $S P L$ dan frekuensi dominan masing-masing 
berkisar dari $91 \mathrm{~dB}$ sampai $93 \mathrm{~dB}$ dan dari $96 \mathrm{~Hz}$ sampai $621 \mathrm{~Hz}$. Dari pengujian alat pemanen energi akustik berbasis loudspeaker dengan variasi panjang resonator dan dengan sumber kebisingan acak dari mesin kendaraan bermotor dalam penelitian ini diperoleh bahwa resonator dengan panjang $112 \mathrm{~cm}$ merupakan resonator yang paling optimal yang menghasilkan tegangan $r m s\left(V_{r m s}\right)$ rata-rata (pada resistor beban $100 \Omega$ ) dan daya listrik rms $\left(P_{r m s}\right)$ rata-rata tertinggi yaitu masing-masing $(144 \pm 3) \mathrm{mV}$ dan $(0,21 \pm 0,01) \mathrm{mW}$. Hasil ini menunjukkan bahwa alat pemanen energi akustik yang diuji ini cukup efektif untuk diaplikasikan apabila dibandingkan dengan hasil penelitian Sifa (2018) di skala laboratorium memperoleh daya $r m s$ sebesar $(0,28 \pm 0,01) \mathrm{mW}$ pada $S P L$ kebisingan $100 \mathrm{~dB}$ juga dengan panjang resonator $112 \mathrm{~cm}$.

\section{SARAN}

Untuk penelitian lapangan lebih lanjut diharapkan lebih mengantisipasi dampak fluktuasi dari sumber kebisingan acak dengan mencari panjang resonator yang tidak terlalu sensitif terhadap fluktuasi frekuensi dominan kebisingan acak sehingga daya listrik rms yang dihasilkan dapat lebih stabil, dengan tetap mengusahakan agar daya listrik rms yang dihasilkan tetap tinggi.

\section{DAFTAR PUSTAKA}

Dimastya, R. A. (2018) Pembuatan Dan Pengujian Alat Pemanenan Energi Akustik (Acoustic Energy Harvester) Menggunakan Loudspeaker Dan Resonator Helmhotz Sebagai Sumber Energi Alternatif. Skripsi, FMIPA Universitas Gadjah Mada.

Fatikasari, T. (2018) Uji Eksperimental Kemampuan Berbagai Loudspeaker Komersial Sebagai Pengkonversi Energi Bunyi Menjadi Energi Listrik Untuk Aplikasi Alat Pemanen Energi Akustik. Universitas Gadjah Mada.

Horowitz, S. B. et al. (2006) 'A MEMS acoustic energy harvester', Journal of Micromechanics and Microengineering, 16(9), pp. 13-16.

Khan, F. U. and Izhar (2016) 'Electromagnetic energy harvester for harvesting acoustic energy', Sadhana-Academy Proceedings in Engineering Sciences. Springer India, 41(4), pp. 397-405.

Pillai, M. A. and Deenadayalan, E. (2014) 'A review of acoustic energy harvesting', International Journal of Precision Engineering and Manufacturing, 15(5), pp. 949965.

Setiawan, I. (2019) 'Studi Eksperimental Penggunaan Loudspeaker Sebagai Pengkonversi Energi Bunyi Menjadi Listrik Dalam Alat Pemanen Energi Akustik ( Acoustic Energy Harvester )', Jurnal Teknologi 11(1), pp. 9-16.

Sifa, M. (2018) Studi Eksperimental Pengaruh Panjang Resonator Terhadap Daya Listrik Yang Dihasilkan Oleh Alat Pemanenan Energi Akustik (Acoustic Energy Harvester), Skripsi FMIPA Universitas Gadjah Mada.

Triboesono, A. (2017) Statistik Ketenagalistrikan 2016. 30th edn, Dirjen Ketenagalistrikan Kementrian ESDM. 30th edn. 